\title{
Reflections Of Movement And Health In The Current Sports Cultural Anthropology
}

\author{
Professor PhDr. Josef Oborný, PhD. \\ Comenius University in Bratislava, \\ Faculty of Physical Education and Sports \\ Department of Sport Educology and Sport Humanities \\ Mgr. Andrea Bernhauserová \\ Comenius University in Bratislava, \\ Faculty of Physical Education and Sports \\ Department of Sport Educology and Sport Humanities \\ Mgr. Michal Bábela \\ Comenius University in Bratislava, \\ Faculty of Physical Education and Sports \\ Department of Sport Educology and Sport Humanities
}

\begin{abstract}
The article presents a theoretical scientific study of movement, sports movement, health and spiritual health. It informs about the basic aspects of the purpose of the human movement and it drafts the range of the term spiritual health. The study is teleological heading to detection how the cultural anthropology interprets the human movement and health by the current needs of a man and by his current comprehending, and at the same time, to the presentation of the detections of cultural anthropology of sport in the area of the human sport movement. It applies methodological instruments of the qualitative research, which include logically consistent contemplation, selective teleological compilation and non-participant observation via electronic medium. From the cultural anthropological point of view, it defines the basic aspects of health: Personal aspect - express the health care as an indicator of cultural behaviour pattern of an individual. Social aspect - health is reflected as an irreplaceable social value, which is used by every individual of a given society. In a global aspect, the health is reflected as an universal value and the health care gains literally a global form, e.g. in a fight against the possible forms of a certain world pandemia. In the end, the study formulates an assignment which confronts the cultural anthropology of sport with the research of a nonreligious spirituality, which together with some other factors in a great measure configurator the quality of an existent human life.
\end{abstract}

Key words: Cultural anthropology, sport movement, purpose of movement, health, spiritual health.

\section{INTRODUCTION}

Our specialised literature focusing on health and sport movement has recently emphasised the need of more exact revelation of health structures, its layers and influence of movement on individual segments of health. In these intentions sport cultural anthropology has started to develop in our conditions and it is inspired by results of the research of sport movement presented in foreign literature. The notion "spiritual health" has also gradually infiltrated into 
our thinking from foreign sources. We think the sports cultural anthropology as a whole shall be paid more attention in our sport as well as academic fields.

\section{Purpose}

The purpose of theoretical research which is presented in this article is to find out how cultural anthropology interprets movement and health within the intentions of actual needs of a human and to present sports cultural anthropology findings in the field of sport human movement. In theoretical studies, stated figuratively, the purpose often has a form of torn end of a rope whereas in non-sufficiently elaborated issue the aim can be rather an anticipated cognitive value which we are only looking for.

\section{METHODOLOGY}

The methodology is adequate to theoretical character of the study. Creative logically consistent contemplation and selective teleological compilation is applied from sources of human movement and health theory; inductive conclusion, excerption and commenting of opinions related to health and movement; passive observation through an electronic medium.

\section{The history and present of cultural anthropology}

Cultural anthropology as a notion denotes American anthropologic tradition for which the notion of culture represents central and typical notion widely understood. It was formed almost together with social anthropology in the second half of the $19^{\text {th }}$ century and its research scope was expanded for so called alien-cultural dimension (Linhart, Petrusek, Vodáková, Maříková, 1996, 94-95). With this cultural anthropology orientation the study of "aliencultural" medicine and health practices of so called foreign / alien cultures is also connected. In such sense the culture denominates all specifically non-genetic phenomena in a way as they are expressed in artefacts, normative, regulative and ideas accepted by members of a specific society (Dohnalová, Malina, 351). The attribute "cultural" is very often connected with the attribute "social" and therefore we often meet with the social-cultural anthropology notion in the specific relations. Cultural and social anthropology belongs to a category of social sciences, which study social cultures. It specifically orientates on formation, development and comparison of cultures and culture importance for a human. Cultural anthropology also deals with the issue of how people understand "their" culture and therefore it deals with local traditions and regional history.

Nowadays cultural anthropology has expanded its research scope also into the area of sport $\mathrm{t}^{\mathrm{i}}$ and varieties of cultural sport movement forms. ${ }^{\text {ii }}$ This way tradition in defining the notion of sport as a cultural phenomenon of modern society has been developed. Some theses even examine basic forms of human movement - walking and running - in historical cultural contexts. „This means that culture from an individual requires a rigorously delimitated use of the body which is being reflected in the human body and human movement behaviour (Mačák, 2007, 31). iii The mechanism of movement behaviour preservation in individual cultures is quite simple. In each culture movement behaviour is transferred from one generation to another and therefore all people who develop their ontogenesis in a specific system adopt specific features of a respective movement behaviour in a certain historic time and geo-area.

Similarly as movement also health can become a natural element of cultural anthropology scientific interest. From the point of social anthropology we define health (according to WHO) as a condition of physical, spiritual and social comfort which is the result of harmony under a mutual influence of organism and environment; from this point this does not concern a simple 
non-presence of diseases (Dohnalová, Malina, 728). Care for health on a social level, from any point of view, results from relevant cultural context in which an individual lives.

Cultural anthropology reflects and understands health as a cultural phenomenon from the point of several aspects. Personal aspect - expresses care for health as an indicator of cultural formulas of an individual person's behaviour. Social aspect - health is reflected as an irreplaceable social value used by each individual of a specific society. From the point of global aspect health is reflected as a human value and care for health acquires literally a global form, like in fight against any potential forms of a specific world pandemics. In a specific sense we can also mention national aspect of health while nations, historical and gradually the present ones are also the scope of interest of the cultural anthropology. There were times when institutes of national health were mentioned in our country.

The notion of multiculturalism has been shown in present cultural anthropology as well as for the last decades in various forms and mutations. From this point we can perceive the movement leading to health and supporting health as an expression of so called cultural alteration (from Latin word alter - other, other way; we remind that from this word the notion of alternative medicine originates). Cultural alteration expresses in other words cultural difference, alteration, variation. It is one of the central notions of culturological studies and ethnology and this way also the cultural anthropology.

In its traditional expression it mainly denominated phenomena, superficial and inter-cultural differences, like in rituals or institutions of community life. In a modern culturological science it focuses on detection of depth differences in perception of ethic fact and value paradigm of ethnics. From the historical point of view we can only remind of the inspiring strength of wisdom of ancient nations and the need to „understand approach of natural nations to life and nature and ... respect of their values and ideas (Hurych, 2013, 119)“. Not the ancient historic nations themselves, but us, representatives of modern culture have dangerously yield to phenomena, superficial forms of our culture. These internally anchored cultural differences are not only described by the cultural anthropology, but also functionalised in favour of (often artificial) coding of cultural identity (Malina, 2009, 65). Some social sciences nowadays present and point out to failure of multiculturalism ideas, mainly in the religious and political area. However, this is not the scope of our interest.

\section{Perception of sport movement and health in cultural anthropology}

Human body is not the only bearer of various forms of sport movement. Sport is a sophisticated activity, some authors also talk about spiritual activity (Hurych et al. 2013). Sport also represents challenges leading to human soul, it is an enthusiastic activity soaked through with ethos and it does not only lead to human health support. Movement expresses (health) condition and dynamics of the whole human being. The movement concerns everything which exists inside a human being and which soaks through from inside. Movement concerns mental and spiritual health of a human very intensively.iv "Through movement all possible forms of human behaviour and any of its inner movements are communicated (Hodaň, 2000, 105).“

Movement is a speech of voiceless and silent person. Other author goes even further in this sense. Status of a human is a structure of material (body, necessary condition of a human existence), ideal (soul, i.e. psychical capabilities, thinking, feelings), idealized (spirit, personal dimension being expressed in existence execution of values), relational (social anchoring of person as a social and cultural human being). From this one can conclude that "spirituality is an expression of spiritual dimension (or expression) of human existence (and this way it 
delimitates area of living which is characterised with personal uniqueness), and at the same time when we consider physical, psychical and social health we can also consider independent modus of spiritual health (Jirásek, 2015, 176)“." Spiritual health is expressed by spiritual comfort notion (Jirásek, 2015, 179).

As long as I accept premise that spirituality is an ideal subbase of spiritual health then we have to emphasise the existence of various forms of spirituality. Just for illustration we will state an example of Brugger's attitude to the case. Spiritualism is interpreted (in contradiction to materialism and in compliance with philosophical schools of the past) as learning about the fact of spirit or spiritual beings. Metaphysical spiritualism tries to understand the being from a spirit. Monistic form of spiritualism assumes that spirit is the fact / reality, i.e. one, absolute spirit. Psychological spiritualism teaches about spirituality of a soul (Brugger, 1994, 402-403). Our conception demystifies and demythologises spirituality, respectively it does not understand it in mystic but mythological sense. Based on the above mentioned we can delimitate in our understanding the notion of spiritual health as follows.

- A human stands on his own feet, not only through his lower extremities but also through his own head

- He is symbolised by inner life balance, harmony and authenticity (he stands on his own feet).

- Spiritually healthy person has a vision of actual and future life, vision which goes forward. It is not only a shallow Carpe diem. It is actual (real) Carpe diem.

- Natural attitude to death. The fact that all of us die one day is spontaneous, and it is not the reason for mental panic and mystic understanding of the notion of the fledged, but ambiguous Memento mori. We do not recommend to live and think about death in the sense of some spiritualism, but within the intentions of spirituality. Life and death are in a dyadic relation: the one who did not live, hasn't died, the one who didn't die, has not lived. Spiritualism and spirituality is strictly differentiated by Kosiewicz (Spiritualism versus spirituality) and he adds: spirituality (spiritual side) in popular sense shall be connected with an effort to implement /execute values which are in the upper part of value spectrum, it interiorizes and approves of this hierarchy of values (spirituality in the popular sense of the word is supposed to be connected with striving for realisation of values which are at the top of internalized and approved hierarchy of values; Kosiewicz, 2009, 287, 290).

- Intellectual human world characterises inner consistent world opinion as "the basic explanatory principle which a person in his life follows (Dohnalová, Malina, 2006, 618619)."

- Inclination to the whole value spectrum of material and non-material character which support other parts of life and quality of life.

- Adoption of personally created and lived moral values which are not in conflict with the good.

- Unity of physical and non-physical segment of the human being.

- Creative acceptance of the whole spectrum of traditional community standards and participation at their cultivation. In similar relation Bednár talks about homo creator (inveniens) as one of the formulas of human being who not only got used to the environment but is able to construct and change such environment (Bednář, 2009, 14).

- Person represents a natural element of relevant culture in all sides, but mainly through lived spirituality (national or sport one, for example).

Let's look at sport movement and its purpose in connection to life and sense of life, in connection to objective life needs in heath and with regard to subjective life needs of a human. 
In other words we shall talk about some levels of human movement sense (sport one) and for a human. From the point of differentiation of these levels we would like to state their basic scale.

- Level of satisfying a wide range of physical biological needs of a human body through movement. „Necessarily needed volume of sport is reducing in conditions of economically developed countries which calls for the urge to replace such deficit with artificial forms of movement activities (Hurych, 2010, 15)." This level is relevant to the physical health predominantly.

- Level of satisfying the need of „discharging“ animal instincts of animal joy and anger in which the need of sublimating animosity pulsates. It is an elementary, authentically anthropological and often subconscious layer of sense of movement in sport.

- Level of satisfying psychological needs and in lower „version“ it covers movement for instance, which sense can't be explained, but even though we perform it. There are spontaneous expressions of joy and disappointment, overcoming of anxiety through movement activity and strengthening the feeling of elementary self-confidence.

- Level of hedonistic human needs satisfaction which is for instance presented by the need to perceive the feeling of endorphins producing happiness, need of delight and pleasure repletion, need of blessedness feeling, feeling of psychical health. Among recreational sportsmen who participate at demanding sport events there are many recession-like persons, experimenting ones, but also hazarding persons who „undertake such events" mainly because of their hedonistic need satisfaction but not from the point of the fact that it is needed for their health.

- Level of eudaemonistic need satisfaction - needs for feelings of happiness from the own will strength, from admiration of spectators, friends, relatives, family, parents, school mates, rivals / competitors.

- Level of existentialist need satisfaction may know the answers to questions like „Who am I“, „What are my maximum possibilities", "Where is my existence boarder of preserving health and life" at sport movement activities. From personal experience we can give evidence from marathon where there are dilemmatic situations of a sportsman in condition of actual physiological and psychical exhaustion very common. Border poles of such situation include giving up or walking (staggering) to the end or stated in other words, purposeless continuing in run accompanied with hazard and threat of life and health or sensible (purposeful) but humiliating resignation from competition / run.

- Level of philosophical need satisfaction - fusion with nature at movement activities in the countryside, acquiring the feeling of unity with the whole natural environment, adoption of health potential of such environment.

- Level of metaphysical need satisfaction - fusion with cosmic environment, achievement of a condition of calm sport mind, acquisition (achievement) of ataraxia and sport nirvana, completion or better said, execution of catharsis. So as Jirásek states „Spirituality is one of the factors which are used to get connected with good health. However, this connection can be assumed in two levels: phenomenon of spirituality and its influence on health is examined or the individual element of health, spiritual health is constituted (Jirásek, 2015, 179)."

The problem of sport movement purpose for quality of human life is possible to find out through methodological tools of qualitative research predominantly. In connection to specified levels of human movement purpose in relation to its needs we can apply the same "formula“, which, however, states such forms of movement which are attributed the term conscious (and being-aware) purpose of movement (VZP). In such case: VZP $=\mathrm{f}(\mathrm{HO}, \mathrm{RH}, \mathrm{RPZ}, \mathrm{RSVU})$, stated in word: level of being aware of the purpose of movement is the function of various variables: $\mathrm{HO}$ -value orientation of a human; RH - scale of values; RPZ - relevance of movement for drawn 
levels of need satisfaction (in a common life this represents the relevance of movement for human health in a way the person-sportsman subjectively perceives it); RSVU - relevance of movement for self-expression and self-execution. Of course we can consider other variables in this level. Purpose of our movement in serving our health and quality of life can't be exactly expressed by any algebraic function and formula. The purpose is connected to an objective, sometimes it can also identify with the objective. It is good when such objective is represented by health.

Let's get back to the issue of sport movement purpose layers in this regard. In Zürich, at the European Championship in athletics a very interesting marathon was run. The run of almost 25 kilometres was led by a brave solo run of Marcin Chabowski, the Polish runner. However, he run out of strength, after 34 . Km, when he was overrun by Daniele Meucci (later winner) and the exhausted runner resigned from competition shortly. He stopped only when he saw to be overrun by naturalized Polish runner of Ethiopian origin, Yared Shegumo. He stopped in a kick, obviously physically and psychically exhausted, at the legendary $35^{\text {th }}$ (36.) kilometre. What was the purpose of his independent run? Such long marathons are never and nowhere run with such tactic way, with purpose to win. His solo, approximately 25-kilometre long run had a „purposeless“ mission at the first sight. However, after so long 25 kilometres the whole Zürich in form of spectacles was clapping along the track. Applause of spectators is a „Garden of Heaven" for a sportsman! The athletic professionals and laic audience in front of TV was given itself a question whether another boarder of human possibilities is to be overcame or whether the attempt by Marcin Chabowsky fails, literally whether the runner falls down or not. Audience (professionals and laic persons) thought about purpose of Chabowsky's escape and many wished him to win. Those knowing the secret of marathon run have but shaken their heads over his running strategy to reach success or to manage the track.

It is shown that purpose of each movement is primarily in each person itself and health as resulting effect represents its added cultural value. Purpose of movement is objective. Sport movement but represents a cultural movement. There are actually available scientific parameters for its personal quantification. Exhausted marathon runner did not definitely philosophise about the purpose of human movement or the purpose of sport movement in a life of a person. However, on Sunday 17th August 2014 the problem was again unknowingly raised in Zürich by such performance.

The purpose of human sport movement has several layers, it is placed in several layers. The health itself is not represented in each of such layers as an effect of movement. As far as personal inner level is concerned this has often a hidden, or even tabooed form. M. Chabowski, the marathon runner revealed something from his personal intentions. „Today I tried to take my chance, but I didn't succeed. I was very well prepared for this marathon, in my training with the coach we added runs up the hill so that I could be well prepared for any traps along the track. During my escape there was only one idea in my head - to run with my own pace, even my rhythm and success at the end. Biliary colic (i.e. gallbladder attack) took all my strength away and I become exhausted. I do not regret anything, I did my best and I gave everything I could into the run. Thank you for all your words of support and I would like to thank to everybody who helps me each day he/ she can so that I could continue in my sport fighting. I would like to apologise to my coach for this situation and would like to thank him for his assistance (Chabowski, 2014)." The marathon runner also admitted to be completely „washed out" from energy. Of course the pain also paid its role in this case, i.e. bodily, moral and psychical one. The pain is in no way considered as knowing purpose of sport movement, purpose of practising sport or even a feature of health. Let's look in this connection to the picture (1). 
Pict. 1. 42. Year of International evening run through Bruntál. MVBB - 45. In:http://olympiabruntal.cz/view.php?cisloclanku=2014060013

Brief comment to picture: quality of care for our health in relevance to movement, specifically sport movement, shall be definitely verified by senior's age of a human.

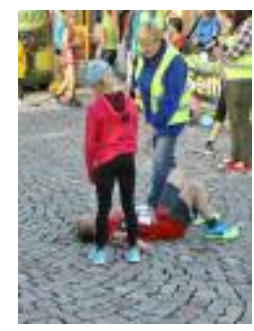

\section{CONCLUSION}

During its existence cultural anthropology always examined historical types of spirituality and their connection to human movement and health. In the past (in human history) this mainly concerned religious types of spirituality and in this sense conditioned approaches to movement and health. Mostly it concerned polytheistic or animistic religions and pragmatically motivated movement. The cultural anthropology is actually going to face tasks of examining non-religious spirituality which, into certain extent together with other factors, configure quality of life of a contemporary person. These „other" factors cover culturally led sport movement. Based on this contours of sport cultural anthropology are formed. Health is a structured phenomenon of a human life. We paid more attention to spiritual health as this is less monitored scientific issue in our conditions. Human characterised by spiritual health, stands on his own feet not only through his lower extremities but also through his own head. He is symbolised by inner life harmony, balance and authenticity (he stands on his own feet). Spiritually health person has a vision of its actual and future life which moves him forward.

\section{References}

BEDNÁř, M. (2009). The human physical activity on biodrome. Way of life (not only) in terms of kinanthropology. (In the original: Pohyb člověka na biodromu. Cesta životem (nejen) z pohledu kinantropológie). Prague: Karolinum. 190 pages. ISBN 978-80-246-1665-0.

BRUGGER, W. (1994). The philosophical dictionary. (In the original: Filosofický slovník). Prague: Naše vojsko. 1. vyd. 640 pages. ISBN 80-206-0409-X.

DOHNALOVÁ, M. and MALINA, J. (2006). The dictionary of anthropology of civil society. (In the original: Slovník antropologie občanské společnosti. Brno: CERM. 778 pages. ISBN 80-7204-394-8.

DZIUBIŃSKI, Z. (ed.). (2008). The humanistic aspects of sport and tourism. (In the original: Humanistyczne aspekty sportu i turistyki). Warsaw: AWF. 471 pages. ISBN 978-83-924538-4-0.

HODAŇ, B. (2000). The physical culture - the socio-cultural phenomenon - basis and relations. (In the original: Tělesná kultura - sociokulturní fenomén - východiska a vztahy). Olomouc: Palacký University. 235 pages. ISBN 80 244-0201-7.

HURYCH, E. (2010). The potentialities of transfer from theory to practice in the field of philosophic kinantrophology. (In the original: Možnosti transferu od teorie k praxi v některých oblastech filosofické kinantropologie). In The physical culture, 2010, 33 (3), pp. 7-26. ISSN 1211-6521.

HURYCH, E. (2013). The stay and physical activity in the nature and their spiritual dimension. (In the original: Možnosti transferu od teorie k praxi v některých oblastech filosofické kinantropologie). In HURYCH, E. (ed.). (2013). The spirituality of physical activities. (In the original: Brno: Masaryk University. 251 pages. ISBN 978-80210-6207-8. 
HURYCH, E. (ed.). (2013). The spirituality of physical activities. (In the original: Spiritualita pohybových aktivít). Brno: Masaryk University. 251 pages. ISBN 978-80-210-6207-8.

CHABOWSKI, M. (2014). In: https://pl-pl.facebook.com/Chabowski.Marcin/17.08.2014 (page viewed 27. 05. 2015).

JIRÁSEK, I. 2015. The spirituality and health: ideological base for reasearch of empirical data. In Czechoslovak psychology. (In the original: Spiritualita a zdraví: ideové podloží pro zkoumání empirických dat. In In Československá psychologie). ISSN 0009-062X; 1804-6436 (electronic version), 2015, Volume LIX, Issue number 2, pp. 174-186.

KOSIEWICZ, J. (2006). The philosophical aspects of physical culture and sport. (In the original: Filozoficzne aspekty kultury fizycznej i sportu). Warsaw: Wydawnictwo BK. 462 pages. ISBN 83-916859-7-7.

KOSIEWICZ, J. (2009). Sport and Philosophy. From methodology to Ethics. Warsaw: Wydawnictwo BK. 316 pages. ISBN 978-83-89829-13-9.

LABUDOVÁ, J. and KRAČEK, S. (2014). The selected health problems of adults and their physical activity. In Krajčovičová, Z., Meluš, V., Králová, E. \& Král, L. (eds.). (2014). THE PHYSICAL ACTIVITY AND HEALTH XI.: The physical activity and healthy lifestyle - The sport and sport training. The proceedings of the international scientific conference. (In the original: Vybrané zdravotné problémy dospelých a ich pohybová činnost'. In Krajčovičová, Z., Meluš, V., Králová, E. \& Král, L. (eds.). 2014. POHYB A ZDRAVIE XI.: Pohybová aktivita a zdravý životný štýl - Šport a športový tréning). Trenčín: Faculty of Health Care, Alexander Dubček University in Trenčín. 216 pages. ISBN 978-80-8075-643-7.

LINHART, J., PETRUSEK, M., VODÁKOVÁ, A. and MAŘÍKOVÁ, H. (1996). The great dictionary of sociology. (In the original: Velký sociologický slovník). Prague: Karolinum. 747 pages. ISBN 80-7184-310-5.

MAČÁK, J. (2007). The walking and running in cultural context. (In the original: Chôdza a beh v kultúrnom kontexte). Bratislava: Comenius University, Faculty of Physical Education and Sports. 135 pages. Dissertation thesis.

MALINA, J. (ed.). (2009). The anthropological dictionary (or what should everyone know about the human). (In the original: Antropologický slovník (aneb co by mohl o člověku vědět každý človek). Brno: Akademické nakladatelství CERM. 4736 pages. ISBN 978-80-7204-560-0. 